\begin{tabular}{|c|l|}
\hline Title & Synthetic study on dolastatin 16: concise and scal able synthesis of two unusual amino acid units \\
\hline Author(s) & U mezawa, Taiki; Sato, A kinori; A meda, Y asuto; Casal me, Loida O.; Matsuda, Fuy uhiko \\
\hline Citation & $\begin{array}{l}\text { Tetrahedron letters, 56/1), 168-171 } \\
\text { https:/doi.org/10.1016/.tetlet.2014.11.054 }\end{array}$ \\
\hline Issue Date & 2015-01-01 \\
\hline Doc URL & http://hdl.handle.net/2115/58057 \\
\hline Rights & ○ 2014 Elsevier Ltd. A Al rights reserved. \\
\hline Type & article (author version) \\
\hline File Information & 2014.11.10. TL Rev.pdf \\
\hline
\end{tabular}

Instructions for use 


\section{Graphical Abstract}

Synthetic Study on Dolastatin 16: Concise

Leave this area blank for abstract info. and Scalable Synthesis of Two Unusual Amino Acid Units

Taiki Umezawa,* Akinori Sato, Yasuto Ameda, Loida O. Casalme, Fuyuhiko Matsuda*

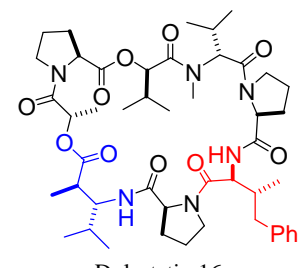

$$
\text { Dolaphenvaline }
$$


Tetrahedron Letters

journal homepage: www.elsevier.com

\title{
Synthetic Study on Dolastatin 16: Concise and Scalable Synthesis of Two Unusual Amino Acid Units
}

\author{
Taiki Umezawa,* Akinori Sato, Yasuto Ameda, Loida O. Casalme, and Fuyuhiko Matsuda* \\ Division of Environmental Materials Science, Graduate School of Environmental Science, Hokkaido University Sapporo 060-0810, Japan
}

\section{ARTICLE INFO}

\section{Article history:}

Received

Received in revised form

Accepted

Available online

\section{Keywords:}

Dolastatin 16

Unusual amino acid

Total synthesis

Mannich reaction

Organocatalyst

\section{ABSTRACT}

A convenient and scalable synthesis of two unusual amino acid units found in dolastatin 16, dolaphenvaline and dolamethylleuine, is described. Dolastatin 16, which was first isolated from the sea hare Dolabella auricularia by Pettit, exhibits not only strong inhibition of growth for a variety of human cancer cell lines but also potent antifouling activity against the larvae of the barnacle Balanus amphitrite. The key element of the synthesis is an organocatalytic Mannich reaction to construct two contiguous stereocenters in the amino acid units with almost complete enantio- and diastereoselectivity.

2009 Elsevier Ltd. All rights reserved.
Dolastatin 16 (1), a macrocyclic depsipeptide, was first isolated by Pettit as a potential antineoplastic metabolite in 1997 from the sea hare Dolabella auricularia, collected in Papua New Guinea (Fig. 1). ${ }^{1}$ This unique depsipeptide proved to be a strong growth inhibitor for a variety of human cancer cell lines and a candidate for further development. Five years after the original report, the isolation of $\mathbf{1}$ from a Madagascan cyanobacterium, Lyngbya majuscule, was described by Gerwick. ${ }^{2}$ With regard to structural features, $\mathbf{1}$ contains the new and unusual amino acid units dolaphenvaline (2) and dolamethylleuine (3). Although the stereostructures of $\mathbf{2}$ and $\mathbf{3}$ were not assigned in these publications, their absolute configurations were determined to be $(2 S, 3 R)$ and $(2 R, 3 R)$, respectively, through X-ray crystallographic analysis of $\mathbf{1}$ performed by Pettit in $2011 .^{3}$
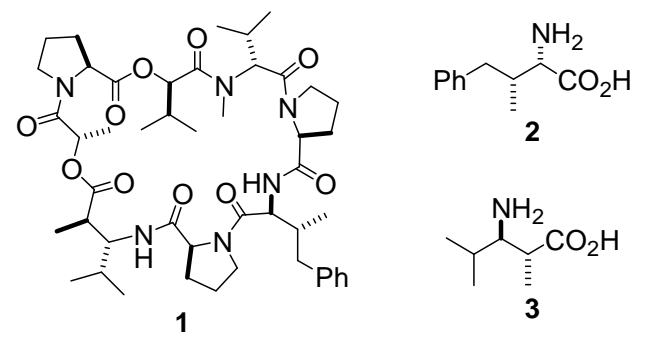

Figure 1. Dolastatin 16 (1) and the unusual amino acid units 2 and $\mathbf{3}$

In 2010, Tan reported that $\mathbf{1}$ showed strong antifouling activity $\left(\mathrm{EC}_{50} 0.003 \mu \mathrm{g} / \mathrm{mL}\right)$ against the larvae of the barnacle
Balanus amphitrite, as well as low toxicity $\left(\mathrm{LC}_{50} 20 \mu \mathrm{g} / \mathrm{mL}\right){ }^{4}$ Biofouling - that is, adverse growth of marine organisms on manmade submerged structures - results in significant economic and environmental problems. Tributyltin (TBT), ${ }^{5}$ which inhibits the settlement of larvae, has been widely used all over the world for this purpose since the early 1960s. However, the deleterious effects of TBT on marine ecosystems prompted the International Maritime Organization (IMO) to call in 2008 for a ban on the use of TBT-based antifouling paint on ships. ${ }^{6}$ Since marine organisms prevent fouling of their outer surfaces through the use of natural substances with antifouling properties without causing serious environmental problems, natural antifouling products, especially those with good settlement-inhibiting properties but without biocidal properties, have attracted considerable attention. ${ }^{7}$ Among these, 1 shows promise as a lead compound for the development of new environmentally friendly antifouling agents due to its potent antifouling activity and low toxicity. ${ }^{8}$

Because of its intriguing and unprecedented structure, $\mathbf{1}$ is an attractive target for total synthesis. For the total synthesis of $\mathbf{1}$, synthetic methods for the optically active amino acid units $\mathbf{2}$ and $\mathbf{3}$ must be developed. Syntheses of these unusual amino acid units have been carried out previously. Scheuer synthesized all four stereoisomers of $\mathbf{2}$ from both enantiomers of $\mathrm{N}$-phthaloyl3,4-dehydrovaline (4) during structure elucidation of kulokekahilide-1, a cytotoxic depsipeptide from the cephalaspidean mollusk Philinopsis speciosa. ${ }^{9}$ The synthesis involved a Mizorogi-Heck reaction of $\mathbf{4}$ with iodobenzene and non-diastereoselective hydrogenation of olefin 5 (Scheme 1).

* Corresponding author. Tel.: +81-11-706-2358; fax: +81-11-706-4517. E-mail: umezawa@ees.hokudai.ac.jp (T. Umezawa)

* Corresponding author. Tel.: +81-11-706-4520; fax: +81-11-706-4520. E-mail: fmatsuda@ees.hokudai.ac.jp (F. Marsuda) 
Pettit prepared $N$-TFA-dolaphenvaline (9) from allyl ester 6 through asymmetric Claisen rearrangement of $\mathbf{6}$ to give syncarboxylic acid $\mathbf{7}$ and hydrogenolysis of lactone $\mathbf{8}$ derived from 7. ${ }^{3}$ Pettit also achieved a synthesis of $\mathrm{N}$-Cbz-dolamethylleuine (13) through diastereoselective alkylation ${ }^{10}$ of the $\beta$-amino acid ester 11 prepared from $N$-Cbz-L-valine (10) and cleavage of $t$ butyl ester of anti-ester $12 .^{3}$ Although the two amino acid units have been prepared, total synthesis of $\mathbf{1}$ has not yet been reported

In conjunction with our program directed toward a practical total synthesis of $\mathbf{1}$, we developed a concise and scalable synthetic procedure for the unusual amino acid units $\mathbf{2}$ and $\mathbf{3}$ by using highly enantio- and diastereoselective Mannich reactions promoted by chiral organocatalysts. ${ }^{11,12}$ This method provides flexible access to a wide variety of congeners of $\mathbf{2}$ and $\mathbf{3}$, such as diastereomers and enantiomers, by simply changing the catalyst or starting material. The synthetic plan for both amino acid units (2 and 3) is shown in Scheme 2. We envisioned the derivation of $\mathbf{2}$ or $\mathbf{3}$ from syn- $\beta$-amino aldehyde $\mathbf{1 7}$ or anti- $\beta$-amino aldehyde 20, which were prepared by Hayashi through enantio- and

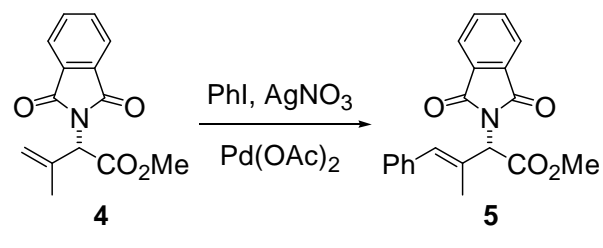<smiles>[2H][C@@H](C[C@@H](N)C(=O)O)[C@H](N)C(=O)O</smiles>

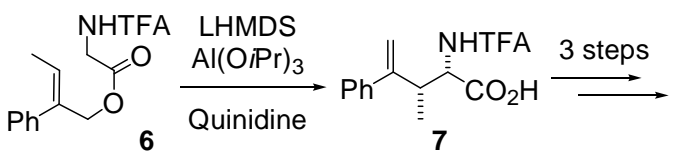<smiles>CC1C(c2ccccc2)OC(=O)[C@H]1NC(F)(F)F</smiles>

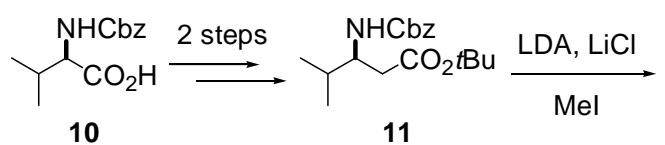

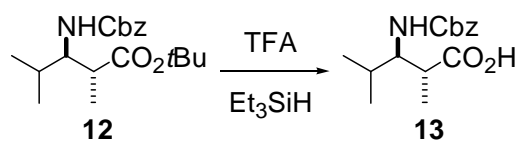

Scheme 1. Previous syntheses of $\mathbf{2}$ and $\mathbf{3}$. diastereoselective Mannich reactions with chiral organocatalysts 16 or $19 .{ }^{13,14}$ Herein, we report the asymmetric synthesis of these unusual amino acid units.

First, we synthesized $N$-Boc-dolaphenvaline (25) as illustrated in Scheme 3. As reported by Hayashi, ${ }^{13}$ a syn-Mannich reaction between propanal (14) and ethyl $\alpha$-imino glyoxylate 15 promoted by the chiral organocatalyst $\mathbf{1 6}$ afforded syn-adduct 17, which was directly treated with Wittig reagent in a one-pot operation to isolate the syn- $\alpha, \beta$-unsaturated ester $\mathbf{2 1}$ in $72 \%$ yield (2 steps) with excellent enantio- and diastereoselectivity $(>95 \%$ ee, $\mathrm{dr}=$ $>95: 5) .{ }^{15,16}$ Conversion of the aldehyde into the $\alpha, \beta$-unsaturated ester was essential for further transformation because the aldehyde moiety of $\mathbf{1 7}$ was labile under the reaction conditions for addition of a phenyl group or removal of the $N$ - $p$ methoxyphenyl ( $N$-PMP) group. One-pot protecting group manipulation followed by ozonolysis produced aldehyde $\mathbf{2 3}$ in $57 \%$ yield (3 steps). While attempted nucleophilic addition of $\mathrm{PhMgBr}, \mathrm{PhLi}$, or $\mathrm{PhCeCl}_{2}{ }^{17}$ to the aldehyde part of $\mathbf{2 3}$ failed, we eventually found that the addition of $\mathrm{PhMgBr}$ took place cleanly in the presence of $\mathrm{ZnCl}_{2},{ }^{18}$ and lactone $\mathbf{2 4}$ was obtained in $67 \%$ yield $(\mathrm{dr}=8: 1) .{ }^{19}$ Reductive cleavage of the benzylic $\mathrm{C}-\mathrm{O}$ bond of $\mathbf{2 4}$ under hydrogenolysis conditions provided $\mathbf{2 5}$ in $93 \%$ yield.
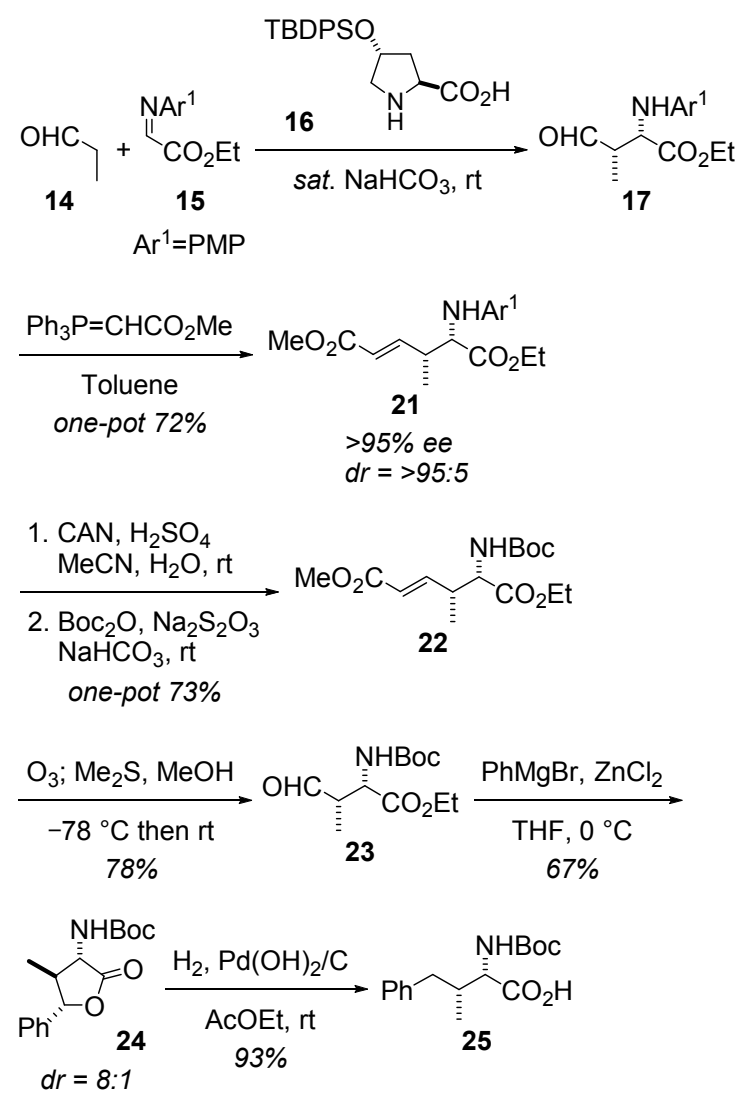

Scheme 3. Stereoselective synthesis of $\mathbf{2 5}$.

TBDPSO,

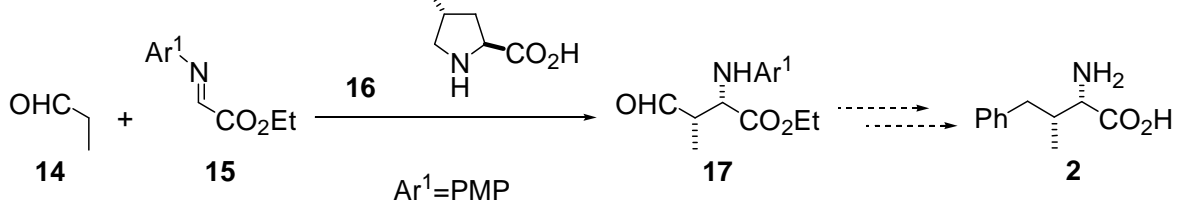

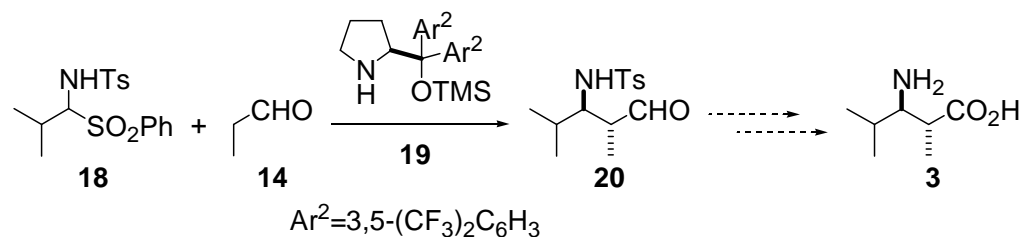

Scheme 2. Synthetic plan for $\mathbf{2}$ and $\mathbf{3}$. 
Table 1. Optimization of anti-Mannich reaction catalyzed by $19{ }^{\mathrm{a}}$

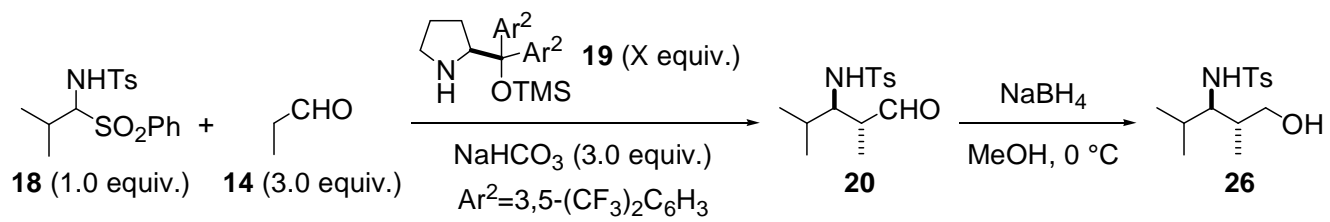

\begin{tabular}{|c|c|c|c|c|c|c|}
\hline entry & $\mathrm{X}$ & Solvent & Temperature & Yield $(\%)$ of $\mathbf{2 0}^{\mathrm{b}}$ & $\mathrm{dr}\left(\right.$ anti:syn) ${ }^{\mathrm{c}}$ & $\% e e^{d}$ \\
\hline 1 & 0.2 & 1,4-dioxane & $\mathrm{rt}$ & 75 & $68: 32$ & 95 \\
\hline 2 & 0.2 & 1,4-dioxane & $0{ }^{\circ} \mathrm{C}$ & 31 & $73: 27$ & 94 \\
\hline 3 & 0.2 & DMF & $0{ }^{\circ} \mathrm{C}$ & 9 & $93: 7$ & 81 \\
\hline 4 & 0.2 & DMSO & $\mathrm{rt}$ & $\mathrm{cm}$ & nd & nd \\
\hline 5 & 0.2 & THF & $\mathrm{rt}$ & 59 & $94: 6$ & 98 \\
\hline 6 & 0.2 & THF & $0{ }^{\circ} \mathrm{C}$ & 44 & $>95: 5$ & $>99$ \\
\hline 7 & 0.2 & THF & $\mathrm{rt}$ & 92 & $92: 8$ & 98 \\
\hline 8 & 0.2 & THF & $0{ }^{\circ} \mathrm{C}$ & 74 & $>95: 5$ & $>99$ \\
\hline $9^{\mathrm{e}}$ & 0.4 & THF & $0{ }^{\circ} \mathrm{C}$ & 76 & $>95: 5$ & 98 \\
\hline $10^{\mathrm{f}}$ & 0.4 & THF & $0{ }^{\circ} \mathrm{C}$ & 75 & $>95: 5$ & 98 \\
\hline
\end{tabular}

${ }^{a}$ For optimizations, the reaction conducted with $30 \mu \mathrm{L}(0.433 \mathrm{mmol})$ of $\mathbf{1 4}$ and $33.2 \mathrm{mg}(0.087 \mathrm{mmol})$ of $\mathbf{1 8} ; \mathrm{cm}=$ complex mixture; nd $=$ not determined. ${ }^{\text {b }}$ Isolated yield of $\mathbf{2 0}$ after column chromatography. ${ }^{\mathrm{c}}$ Determined by ${ }^{1} \mathrm{H}-\mathrm{NMR}$ with alcohol $\mathbf{2 6}$ obtained by $\mathrm{NaBH}_{4}$-reduction of $\mathbf{2 0}$. ${ }^{\mathrm{d}}$ Determined by chiral $\mathrm{HPLC}$ analysis with 26. ${ }^{\mathrm{e}}$ Partial removal of TMS group of $\mathbf{1 9}$ was observed. Recovered $\mathbf{1 9}$ was used after silylation with TMSOTf and Et 3 N. ${ }^{\mathrm{f}}$ For gram scale synthesis, $1.0 \mathrm{~g}(2.6 \mathrm{mmol})$ of $\mathbf{1 8}$ was used.

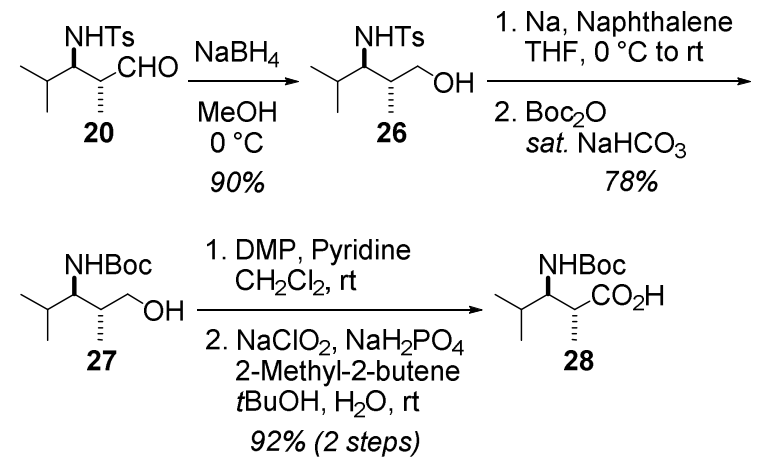

Scheme 4. Stereoselective synthesis of 28.

We then turned our attention to the synthesis of $N$-Bocdolamethylleuine (28). Hayashi reported that an anti-Mannich reaction between aminosulfone $\mathbf{1 8}$ and propanal (14) with chiral catalyst 19 (0.1 equiv.) afforded anti-adduct 20 with high stereoselectivity $(98 \%$ ee, $\mathrm{dr}=88: 12)$ by performing the reaction in 1,4-dioxane at $10{ }^{\circ} \mathrm{C} .{ }^{14}$ For convenient gram-scale preparation of 20, we attempted to optimize the reaction conditions for the anti-Mannich reaction. The results of the optimization aresummarized in Table 1. When the reaction was carried out at ambient temperature following the protocol described by Hayashi, excellent enantioselectivity $(95 \%$ ee) was obtained but diastereoselectivity was low ( $d r=68: 32)$ (Entry 1$)$. Lowering the reaction temperature to $0{ }^{\circ} \mathrm{C}$ caused a significant decrease in chemical yield (Entry 2). We then performed a solvent screen under the same reaction conditions. Although the Mannich reaction proceeded sluggishly in DMF or DMSO (Entries 3 and 4), THF was found to be superior to 1,4-dioxane in achieving the desired stereoselectivity (Entries 5, 6). In particular, 20 was exclusively formed as a single stereoisomer $(>99 \%$ ee, $\mathrm{dr}=$ $>95: 5)$ at $0{ }^{\circ} \mathrm{C}$. However, the chemical yield in THF was moderate at room temperature. A twofold increase in the catalyst loading led to a dramatic increase in chemical yield (Entries 7,8). The chiral organocatalyst $\mathbf{1 9}$ was easily recovered in a yield of $76 \%$ by chromatographic separation of the reaction mixture, and was reused for the same Mannich reaction between 18 and 14 (Entry 9). Under the optimal conditions (with 0.4 equiv. of 19 in $\mathrm{THF}$ at $0{ }^{\circ} \mathrm{C}$ ), the organocatalytic Mannich reaction was successfully used for a gram-scale synthesis of $\mathbf{2 0}$ to afford a comparable yield $(75 \%)$ and stereoselectivity $(98 \%$ ee, $\mathrm{dr}=$ $>95: 5$ ) (Entry 10) to those obtained in a milligram-scale experiment (Entry 8). The resulting 20 was converted to $\mathbf{2 8}$ as shown in Scheme 4. After reduction of $\mathbf{2 0}$ with $\mathrm{NaBH}_{4}$ to alcohol 26, successive removal of the $N$-Ts group and Boc-protection in a one-pot operation gave alcohol 27 in $70 \%$ yield (3 steps). Stepwise oxidation of the primary alcohol to the carboxylic acid gave $\mathbf{2 8}$ in $84 \%$ yield (2 steps).
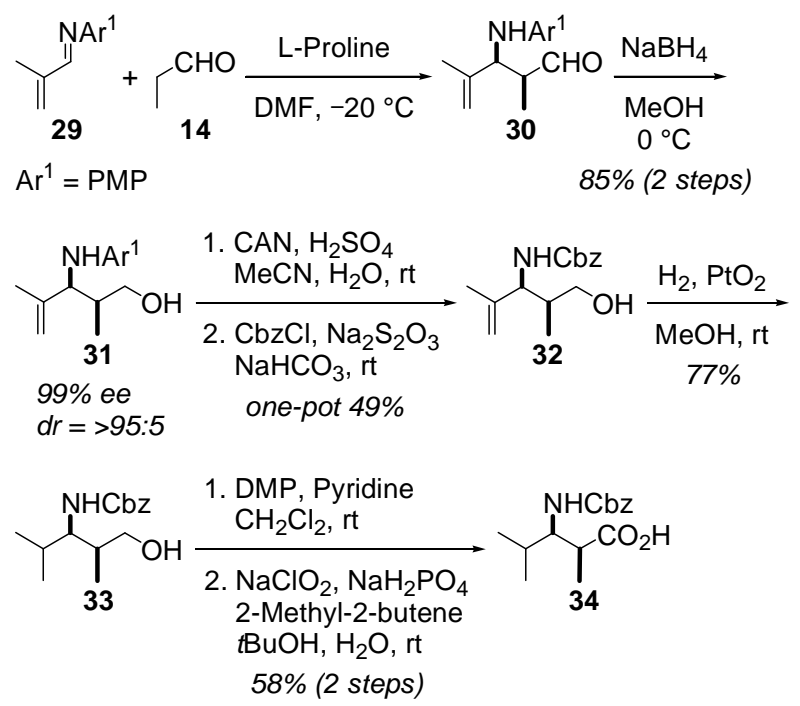

Scheme 5. Selective synthesis of $\mathbf{3 4}$.

We also achieved the synthesis of $N$-Cbz-2-epi-dolamethylleuine (34). A highly stereoselective syn-Mannich reaction of aromatic $N$-PMP-aldimine with propanal (14), catalyzed by Lproline, was reported by Hayashi. ${ }^{20}$ The $\alpha, \beta$-unsaturated $N$-PMPaldimine 29, generated from methacrolein and $p$-anisidine, was subjected to an asymmetric syn-Mannich reaction with $\mathbf{1 4}$. The 1,2-addition reaction occurred cleanly in a highly stereoselective manner $(99 \% \text { ee, } \mathrm{dr}=>95: 5)^{21}$ to give syn-adduct 30 almost exclusively. After $\mathrm{NaBH}_{4}$-reduction of 30, alcohol 31 was isolated in $85 \%$ yield ( 2 steps). One-pot protecting group transformation gave alcohol 32 (49\% yield), which led to 34 via 

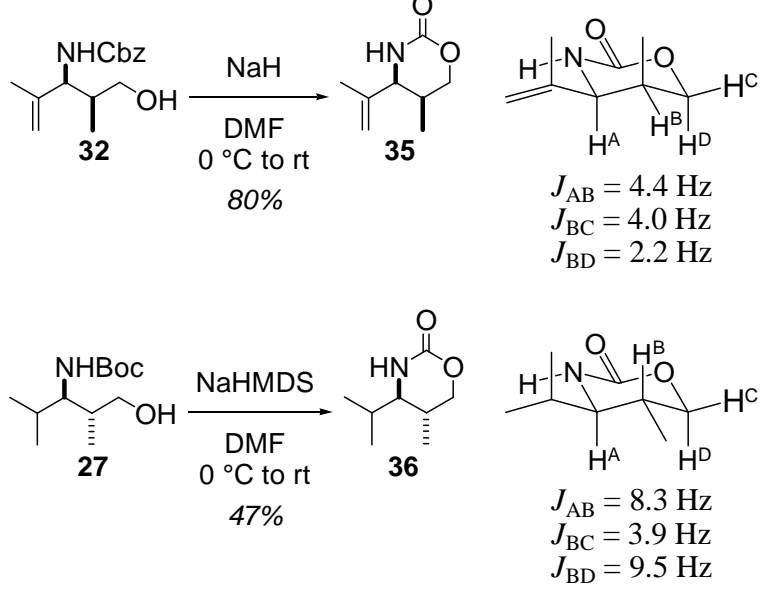

Scheme 6. Confirmation of relative configuration of $\mathbf{3 4}$.

hydrogenation of the olefin ( $77 \%$ yield) and oxidation of primary alcohol 33 to carboxylic acid (58\% yield). The relative configuration of $\mathbf{3 4}$ was determined based on coupling constant analysis of tetrahydro-1,3-oxazin-2-ones $\mathbf{3 5}$ and 36, prepared through base-induced cyclization of $\mathrm{N}$-protected 1,3-amino alcohols 32 and 27, respectively (Scheme 6). Since 27 was derived from the known anti-1,3-amino alcohol $\mathbf{2 6}^{14}$ (Scheme 4), both of the vicinal methine protons $\left(\mathrm{H}^{\mathrm{A}}\right.$ and $\left.\mathrm{H}^{\mathrm{B}}\right)$ of $\mathbf{3 6}$, prepared from 27, were expected to adopt an axial orientation in the chair conformation of the 1,3-oxazine ring. Actually, a larger vicinal coupling constant, $J_{\mathrm{AB}}=8.3 \mathrm{~Hz}$ (axial/axial relationship), was obtained in ${ }^{1} \mathrm{H}-\mathrm{NMR}$ spectrum of 36. The smaller vicinal coupling constant $J_{\mathrm{AB}}=4.4 \mathrm{~Hz}$ (axial/equatorial relationship) for 35 reveals a cis relationship between the vicinal methine protons $\mathrm{H}^{\mathrm{A}}$ and $\mathrm{H}^{\mathrm{B}}$ and the syn-relative stereochemistry of $\mathbf{3 4}$. In contrast, in the L-proline-catalyzed asymmetric Mannich reaction, Lproline always mediates a si-facial attack of the aldimine through an enamine intermediate generated from an aldehyde. ${ }^{22}$ Therefore, the absolute configuration of $\mathbf{3 4}$ is expected to be $(2 S, 3 R)$.

In summary, scalable and concise syntheses of $N$-Bocdolaphenvaline (25) and $\mathrm{N}$-Boc-dolamethylleuine (28), $\mathrm{N}$-Bocprotected amino acid units of dolastatin $16(\mathbf{1})$, were achieved by employing enantio- and diastereoselective organocatalytic Mannich reactions. The synthetic sequence provided subgram amounts of the amino acid units $\mathbf{2 5}$ and $\mathbf{2 8}$ with overall yields of $26 \%$ (5 steps) and $48 \%$ (5 steps), respectively. Furthermore, this synthetic approach is expected to be applicable to gram-scale preparation of various derivatives of these unusual amino acid units through the selection of appropriate chiral catalysts or starting materials. Indeed, $\mathrm{N}$-Cbz-2-epi-dolamethylleuine (34) was prepared according to a similar scheme to that used for $\mathbf{2 8}$. Further studies with the aim of achieving a practical and scalable total synthesis of dolastatin 16 (1) using 25 and 28 are ongoing.

\section{Acknowledgments}

This work was supported by the Sasagawa Foundation.

\section{Supplementary Material}

Supplementary data associated with this article can be found in the online version at http://dx.doi.org/10.1016/j.tetlet.

\section{References and notes}

1. Pettit, G. R.; Xu, J.-P.; Hogan, F.; Williams, M. D.; Doubek, D. L.; Schmidt, J. M.; Cerny, R. L.; Boyd, M. R. J. Nat. Prod. 1997, $60,752-754$.
Nogla, L. M.; Gerwick, W. H. J. Nat. Prod. 2002, 35, 21-24.

Pettit, G. R.; Smith, T. H.; Xu, J.-P.; Herald, D. L.; Flahive, E. J.; Anderson, C. R.; Belcher, P. E.; Knight, J. C. J. Nat. Prod. 2011, 74, 1003-1008.

4. Tan, L. K.; Goh, B. P. L.; Tripathi, A.; Lim, M. G.; Dickinson, G. H.; Lee, S. S. C.; Teo, S. L. M. Biofouling 2010, 26, 685-695.

5. Evans, S. M. Biofouling 1999, 14, 117-129.

6. Horiguchi, T.; Shiraishi, H.; Shimizu, M.; Yamazaki, S.; Morita, M. Mar. Pollut. Bull. 1995, 31, 402-405.

7. Fusetani, N. Nat. Prod. Rep. 2011, 28, 400-410.

8. (a) Kitano, Y.; Ito, T.; Suzuki, T.; Nogata, Y.; Shinshima, K.; Yoshimura, E.; Chiba, K.; Tada, M.; Sakaguchi, I. J. Chem. Soc. Perkin Trans. 1, 2002, 2251-2255; (b) Kitano, Y.; Yokoyama, A.; Nogata, Y.; Shinshima, K.; Yoshimura, E.; Chiba, K.; Tada, M.; Sakaguchi, I. Biofouling 2003, 19, 187-192; (c) Nogata, Y.; Kitano, Y.; Yoshimura, E.; Shinshima, K.; Sakaguchi, I. Biofouling 2004, 20, 87-91; (d) Kitano, Y.; Nogata, Y.; Shinshima, K.; Yoshimura, E.; Chiba, K.; Tada, M.; Sakaguchi, I. Biofouling 2004, 20, 93-100; (e) Nishikawa, K.; Nakahara, H.; Shirokura, Y.; Nogata, Y.; Yoshimura, E.; Umezawa, T.; Okino, T.; Matsuda, F. Org. Lett. 2010, 12, 904-907; (f) Nishikawa, K.; Nakahara, H.; Shirokura, Y.; Nogata, Y.; Yoshimura, E.; Umezawa, T.; Okino, T.; Matsuda, F. J. Org. Chem. 2011, 76, 6558-6573; (g) Umezawa, T.; Oguri, Y.; Matsuura, H.; Yamazaki, S.; Suzuki, M.; Yoshimura, E.; Furuta, T.; Nogata, Y.; Serisawa, Y.; Matsuyama-Serisawa, K.; Abe, T.; Matsuda, F.; Suzuki, M.; Okino, T. Angew. Chem. Int. Ed. 2014, 53, 3909-3912.

9. Kimura, J.; Takada, Y.; Inayoshi, T.; Nakao, Y.; Goetz, G.; Yoshida, W. Y.; Scheuer, P. J. J. Org. Chem. 2002, 67, 1760-1767.

10. Seebach, D.; Estermann, H. Tetrahedron Lett. 1987, 28, 3103 3106.

11. For recent selected examples of asymmetric Mannich reaction with organocatalyst, see: (a) Yang, J. W.; Chandler, C.; Stadler, M.; Kampen, D.; List, B. Nature 2008, 452, 453-455; (b) Chandler, C.; Galzerano, P.; Michrowska, A.; List, B. Angew. Chem. Int. Ed. 2009, 48, 1978-1980; (c) Hayashi, Y.; Urushima, T.; Tsuboi, W.; Shoji, M. Nat. Protoc. 2007, 2, 113-118; (d) Hayashi, Y.; Okano, T.; Itoh, T.; Urushima, T.; Ishikawa, H.; Uchimaru, T. Angew. Chem. Int. Ed. 2008, 47, 9053-9058; (e) Hayashi, Y.; Sakamoto, D.; Shomura, H.; Hashizume, D. Chem. Eur. J. 2013, 19, 76787681; (f) Kano, T.; Yamaguchi, Y.; Maruoka, K. Angew. Chem. Int. Ed. 2009, 48, 1838-1840; (g) Kano, T.; Yamaguchi, Y.; Maruoka, K. Chem. Eur. J. 2009, 15, 6678-6687; (h) Kano, T.; Song, S.; Kubota, Y.; Maruoka, K. Angew. Chem. Int. Ed. 2012 51, 1191-1194; (i) Kano, T.; Sakamoto, R.; Maruoka, K. Chem. Comm. 2014, 50, 942-944.

12. For review, see: (a) List, B. Synlett 2001, 1675-1686; (b) Córdova, A. Acc. Chem. Res. 2004, 37, 102-112; (c) List, B. Acc. Chem. Res. 2004, 37, 548-1557; (d) Notz, W.; Tanaka, F.; Barbas, C. F., III. Acc. Chem. Res. 2004, 37, 580-591; (e) Mukherjee, S.; Yang, J. W.; Hoffmann, S.; List, B. Chem. Rev. 2007, 107, 5471-5569; (f) Ting, A.; Schaus, S. E. Eur. J. Org. Chem. 2007, 5797-5815; (g) Verkade, J. M. M.; van Hemert, L. J. C.; Quaedflieg, P. J. L. M.; Rutjes, F. P. J. T. Chem. Soc. Rev. 2008, 37, 29-41; (h) Pihko, P. M.; Majander, I.; Erkkila, A. in Topics in Current Chemistry, Vol. 291: Enamine Catalysis (Ed.: B. List), Springer, Berlin, 2009, pp 29; (i) Benohoud, M.; Hayashi, Y. in Science of Synthesis: Asymmetric Organocatalysis 1; Enamine Catalysis of Mannich Reactions (Ed.: B. List), Thieme, Stuttgart, 2012, pp 73.

13. Hayashi, Y.; Urushima, T.; Aratake, S.; Okano, T.; Obi, K. Org. Lett. 2008, 10, 21-24.

14. Urushima, T.; Ishikawa, H.; Hayashi, Y. Chem. Eur. J. 2011, 17, 8273-8276.

15. Diastereomeric ratio (dr) was determined by ${ }^{1} \mathrm{H}-\mathrm{NMR}$ with unsaturated ester 21. Enantiomeric excess (ee) was verified by NMR experiments with Mosher's amides obtained from 21 by successive removal of $N$-PMP group and condensation with both of enantiomers of $O$-methyl-mandelic acid.

16. (a) Hayashi, Y.; Samanta, S.; Itoh, T.; Ishikawa, H. Org. Lett. 2008, 10, 5581-5583. (b) Urushima, T.; Yasui, Y.; Ishikawa, H.; Hayashi, Y. Org. Lett. 2010, 12, 2966-2969. (c) Hayashi, Y.; Yasui, Y.; Kawamura, T.; Kojima, M.; Ishikawa, H. Angew. Chem. Int. Ed. 2011, 50, 2804-2807

17. (a) Molander, G. A. Chem. Rev. 1992, 92, 29-68; (b) Liu, H.-J.; Shia, K.-S.; Shang, X.; Zhu, B.-Y. Tetrahedron 1999, 55, 38033830 .

18. (a) Hatano, M.; Suzuki, S.; Ishihara, K. Synlett 2010, 321-324; (b) George, S.; Narina, S. V.; Sudalai, A. Tetrahedron 2006, 62, 10202-10207. 
19. Dr was determined by ${ }^{1} \mathrm{H}-\mathrm{NMR}$ with an amine prepared by deprotection of Boc group of 24. Configuration of benzylic position of $\mathbf{2 4}$ was assigned by ROE study with the amine.

20. Hayashi, Y.; Tsuboi, W.; Ashimine, I.; Urushima, T.; Shoji, M.; Sakai, K. Angew. Chem. Int. Ed. 2003, 42, 3677-3680.

21. Dr was determined by ${ }^{1} \mathrm{H}-\mathrm{NMR}$ with alcohol 31. Ee was confirmed by chiral HPLC analysis with alcohol $\mathbf{3 2}$.
22. (a) List, B. J. Am. Chem. Soc. 2000, 122, 9336-9337; (b) Notz, W.; Sakthivel, K.; Bui, T.; Zhong, G.; Barbas, C. F., III.

Tetrahedron Lett. 2001, 42, 199-201; (c) Córdova, A.; Notz, W.; Zhong, G.; Betancort, J. M.; Barbas, C. F., III. J. Am. Chem. Soc. 2002, 124, 1842-1843; (d) Córdova, A.; Watanabe, S.; Tanaka, F.; Notz, W.; Barbas, C. F., III. J. Am. Chem. Soc. 2002, 124, 18661867. 